УДК 616-089+616.381-002

DOI 10.11603/2414-4533.2018.1.8860

СІ. М. ШЕВЧУК, М. М. ДРОНЯК, О. Я. ПОПАДЮК, М. Б. ФЕДОРКІВ, В. М. ДРОНЯК

Івано-Франківський національний медичний університет

\title{
Результати хірургічного лікування хворих на післяопераційний перитоніт
}

\begin{abstract}
Мета роботи: покращити результати хірургічного лікування хворих на післяопераційний перитоніт, ускладнений абдомінальним сепсисом, шляхом покращення своєчасної діагностики та впровадження оптимальної хірургічної тактики. Матеріали і методи. За 2010-2017 рр. внутрішньоочеревинні ускладнення діагностовано у 209 (2,4 \%) із 8762 хворих, прооперованих у клініці із приводу гострих і хронічних захворювань органів черевної порожнини.

Результати досліджень та їх обговорення. Абсцеси черевної порожнини спостерігали у 142 (67,9 \%) хворих, розповсюджений перитоніт - 67 (42,1 \%) хворих. Міні-інвазивні технології (лапароскопічні втручання, дренування гнійника під контролем УзД) були ефективними у 129 (61,7 \%) хворих. Релапаротомію (РЛ) виконали у 80 (38,3 \%) хворих, з них при розповсюдженому перитоніті - у 61 (91 \%) із 67 хворих, при абсцесах черевної порожнини - у 19 (13,4 \%) із 142 хворих. Перші прояви інтраабдомінальних ускладнень мали характер гострої дихальної недостатності - у 95 (45,5 \%), серцево-судинної недостатності - у 68 (32,5 \%), печінково-ниркової дисфункції - у 46 (22 \%) хворих за відсутності чітких місцевих ознак захворювання. Серед 80 хворих, яким виконали РЛ за шкалою Marshall J.С., 9-12 балів встановлено у 34 (42,5 \%). Одну РЛ виконано у 46 (57,5 \%) хворих. По дві РЛ виконано у 26 (32,5 \%), по три РЛ - у 8 (10 \%) хворих. Виникнення потреби у проведенні повторних РЛ у 34 (42,5 \%) супроводжувалося значним зростанням рівня летальності. Так, після першої РЛ померли 7 (15,2 \%) із 46 хворих, після другої РЛ - 12 (63,2 \%) із 19, після третьої РЛ 6 (75 \%) із 8 хворих. Застосування прецизійної техніки, лаважу черевної порожнини розчинами антисептиків (8-12 л) до чистих промивних вод, інтраабдомінальне застосування “Екстранілу”, назоінтестинальної інтубації тонкої кишки, поряд з іншими методами лікування, сприяли більш швидкій ліквідації ознак абдомінального сепсису, зниженню числа повторних РЛ, зменшенню післяопераційної летальності з 47,7 до 11,1 \%.
\end{abstract}

Ключові слова: післяопераційний перитоніт; релапаротомія; абдомінальний сепсис.

Постановка проблеми і аналіз останніх досліджень та публікацій. Незважаючи на досягнення анестезіології, інтенсивної терапії, впровадження нових методів діагностики і лікування, зокрема, запровадження відеолапароскопічних технологій, структура ускладнень після операцій на органах черевної порожнини та їх наслідки суттєво не змінилися $[1,5,8]$. Гнійно-септичні ускладнення виникають у 3-10 \% оперованих 3 приводу хірургічних захворювань органів черевної порожнини. При виконанні втручань за невідкладними показаннями, особливо на фоні поширеного перитоніту, їх частота зростає до 15-25 \% $[1,6,8]$. Найчастіше серед внутрішньоочеревинних ускладнень, які вимагають проведення релапаротомії (РЛ), розвиваються гнійно-септичні, передовсім - післяопераційний перитоніт (ПП). Протягом останнього періоду у зв'язку зі збільшенням числа операційних втручань на органах черевної порожнини помітно зросла і частота розвитку ПП [2, 3]. На частоту виникнення ПП впливають характер і тяжкість перебігу захворювання, запізніле виконання операційного втручання, тактичні й технічні помилки, в тому числі нераціональний доступ, недостатня санація черевної порожнини, неефективне дренування, невірна оцінка характеру ексудату, грубе маніпулювання на тканинах, недостатність швів порожнистих орга- нів [4, 9]. У хворих на ПП основним етіологічним чинником утворення злук вважають повторні операційні втручання на органах черевної порожнини [1]. 3 метою профілактики утворення злук в останні роки застосовують різноманітні біодеградуючі матеріали у формі плівок та гелю, що на сьогодні ще вивчають в експерименті та клініці [7].

Летальність після РЛ з приводу ПП сягає 23$34 \%$, а при окремих його формах - 70-90 \% [2, $5,7,10]$. Незадовільні результати лікування зумовлені, насамперед, пізньою діагностикою через атипові прояви ускладнень і, відповідно, несвоєчасне виконання РЛ $[1,5,8]$. У більшості хворих ПП розвивається поліорганна недостатність (ПОН) або поліорганна дисфункція (ПОД) [3, 7, 10]. У 67-75 \% померлих при ПОН на автопсії діагностують інтраабдомінальні абсцеси чи їх несановані “залишки”. Вважають, що ПОН/ПОД нез'ясованої етіології у проперованих хворих $€$ індикатором наявності у них недіагностованого вогнища внутрішньоочеревинної інфекції [4]. Причиною незадовільних результатів лікування ПП вважають, зокрема, відсутність уніфікованої сучасної хірургічної тактики лікування. Впровадження нових технологій у хірургії та нових лікарських середників відкривають нові перспективи подальшого покращення результатів лікування цих хворих. 


\section{З ДОСВІДУ РОБОТИ}

У зв'язку з цим набувають актуальності проблема покращення діагностики ПП, удосконалення хірургічної тактики та заходів інтенсивної терапії.

Мета роботи: покращити результати хірургічного лікування хворих на післяопераційний перитоніт, ускладнений абдомінальним сепсисом шляхом покращення своєчасної діагностики та впровадження оптимальної хірургічної тактики.

Матеріал та методи. За 2010-2017 рр. внутрішньоочеревинні ускладнення, які вимагали повторних операційних втручань, діагностовано у 209 (2,4 \%) із 8762 хворих, прооперованих у клініці з приводу гострих і хронічних захворювань органів черевної порожнини. У 142 (67,9 \%) хворих був обмежений ПП у вигляді абсцесів черевної порожнини, у 67 (42,1 \%) - розповсюджений ПП. Мініінвазивні технології (лапароскопічна санація з дренуванням гнійників і черевної порожнини та дренування гнійників стилет-катетером під контролем УЗД) були ефективними у 129 (61,7 \%) хворих. Релапаротомію (РЛ) виконали у 80 (38,3%) хворих, з них при розповсюдженому ПП - у 61 (91 \%) із 67, при обмеженому ПП - у 19 (13,4\%) із 142 хворих.

Для діагностики внутрішньоочеревинних ускладнень поряд із клінічним, лабораторним та рентгенологічним обстеженням використовували ультразвукове дослідження (УЗД), комп’ютерну томографію (КТ), діагностичну лапароскопію. У 95 (45,5 \%) хворих для діагностики абдомінального сепсису додатково визначали рівень молекул середньої маси (МСM) та продуктів перекисного окиснення ліпідів (ПОЛ) - малонового діальдегіду (МД) та дієнових кон'югат (ДК). В цих хворих вивчено частоту і характер ПОН/ПОД і септичного шоку. Оцінку тяжкості стану хворих проводили за шкалою Marshall J. C. (1995).

Результати досліджень та їх обговорення. Класичні симптоми перитоніту (інтенсивний біль, дефанс, симптоми подразнення очеревини) були відсутні у 178 (85,1 \%) із 209 хворих. Розвиток інтраабдомінальних ускладнень супроводжувався клінічною картиною абдомінального сепсису, що передував місцевій симтоматиці на 1-3 доби. Перші прояви інтраабдомінальних ускладнень при ПП з абдомінальним сепсисом мали характер гострої дихальної недостатності у 95 (45,5 \%), серцево-судинної недостатності - у 68 (32,5 \%), печінково-ниркової дисфункції - у 46 (22 \%) хворих на фоні нечіткої місцевої симптоматики.

При аналізі скарг та об'єктивному обстеженні гіпертермію до $39{ }^{\circ} \mathrm{C}$ встановлено у 68,5 \%, та- хіпное (більше 20 на одну хв), тахікардію (більше 90 на одну хв) - у 45,8 \%, зростання числа нейтрофільних лейкоцитів у периферичній крові (більше 9 х $10^{9}$ в 1 л) - у 76,8 \% хворих. Збільшення кількості паличкоядерних нейтрофільних гранулоцитів у формулі крові в межах від 8 до 49 \% виявлено у 52 (24,8 \%) хворих; зменшення кількості лімфоцитів - у 35 (16,7 \%), зокрема менше $10 \%$ - у $18(8,6 \%)$ хворих.

У 172 (82,3 \%) із 209 хворих виявлено гіпопротеїнемію. Про наростання тяжкості печінкової дисфункції свідчило зростання активності АсАТ та АлАТ, які у 31 хворого (14,8 \%) сягали 4,5 та 4,2 ммоль/л-год, відповідно. Рівень загального білірубіну в сироватці крові перевищував верхню межу норми у 34 (16,3 \%) хворих і становив у середньому $(41,6 \pm 4,35)$ мкмоль/л. Рівень креатиніну перевищував верхню межу норми у 83 (39,7 \%) хворих і становив у середньому $(92,6 \pm 9,18)$ мкмоль/л. Рівень сечовини перевищував норму у 79 (37,8 \%) хворих і становив у середньому $(10,13 \pm 1,13)$ ммоль/л.

Рівень МСМ хворих із діагностованим ПП перевищував верхню межу норми у всіх 95 (45,5 \%) обстежених і становив в середньому $(0,545 \pm$ 0,051) ум. од. Концентрація ДК коливалася від 2,967 до 4,832 од оптичної щільності і становила в середньому 4,875 \pm 0,402. Концентрація МДА перевищувала верхню межу норми у 74 (77,9 \%) із 95 хворих, максимально сягала 6,754 нмоль/мл та становила в середньому $(5,976 \pm 0,592)$ нмоль/мл. Це свідчило про значну ендогенну інтоксикацію, яка потенційно могла призвести до критичного рівня ураження життєво важливих органів та систем. Таким чином, у всіх хворих на ПП встановлено ознаки абдомінального сепсису.

Найчастіше ПП виникав після операційних втручань на тонкій і товстій кишці, в т.ч. тромбозу мезентеріальних судин - у 92 (44 \%), підшлунковій залозі при гострому некротичному панкреатититі і гнійному парапанкреатиті - у 39 (18,7 \%), шлунку і дванадцятипалій кишці - 34 (16,3%), позапечінкових жовчних шляхах - у 26 (12,4 \%), травмі органів черевної порожнини - у 6 (2,9 \%), червоподібному відростку при гострому апендициті - у 4 (1,9 \%), інших причин (хвороба Крона, інвагінація/заворот тонкої кишки, перфорація дивертикула товстої кишки) - у 8 (3,8 \%) хворих.

Проаналізовані результати повторних операційних втручань у 80 хворих, де застосування міні-інвазивних технологій було неефективним. Релапаротомію виконали у 61 (91 \%) із 67 хворих на розповсюджений ПП. 3 них у 24 (39,3 \%) при перфорації гострої стресової виразки шлунка чи тон- 
кої кишки, у 15 (24,6 \%) при неспроможності швів міжкишкових анастомозів, у 8 (13,1 \%) при ретромбозі мезентеріальних судин, у 5 (8,2 \%) при гострій злуковій кишкової непрохідністі з некрозом петлі кишки, у 4 (6,6 \%) при неспроможності швів кукси дванадцятипалої кишки, у 3 (4,9 \%) при неспроможності швів пілоропластики, у 2 (3,3 \%) при кишкових норицях як пізніх ускладненнях гострого гнійного панкреатиту, у 2 (3,3 \%) при недостатності швів езофаго- і гастроентероанастомозу, у 2 (3,3 \%) після ятрогенного пошкодження спільної жовчної протоки, у 2 (3,3%) після ятрогенного пошкодження стінки дванадцятипалої кишки під час проведення ЕРХПГ і ЕПСТ.

При обмеженому ПП у вигляді гнійників черевної порожнини РЛ виконали у 19 (13,4 \%) 3 142 хворих. Показаннями до РЛ слугували відсутність прямої траєкторії чи прогнозована неефективність дренування абсцесу під УЗД контролем. Під час РЛ застосовували прецизійну техніку, лаваж черевної порожнини розчинами антисептиків (8-12 л), проводили назоінтестинальну інтубацію тонкої кишки.

У 36 (45 \%) під час РЛ після інтраопераційного лаважу 0,02 \% розчином декасану в черевну порожнину заливали “Екстраніл” в об’ємі 2 л (розчин для хронічного перитонеального діалізу), який не містить глюкози та має високу осмотичну дію. Операцію завершували формуванням закритої черевної порожнини. Ї̈̈ дренування проводили з чотирьох і більше точок двопросвітними чи поліхлорвініловими дренажами, які відкривали через 24 год після РЛ.

У цих хворих в день РЛ за шкалою Marshall J. C. 1-4 бали встановлено у 7 пацієнтів (прогнозована летальність від 0 до 7 \%); 5-8 балів - у 16 (прогнозована летальність 16 \%); 9-12 балів - у 13 (прогнозована летальність 50 \%). Вміст лейкоцитів у периферичній крові в день РЛ становив в середньому 10,3 $\pm 1,2 \times 10 \%$ /л, рівень загального білірубіну в сироватці крові - $(28,6 \pm 2,9)$ мкмоль/л, активність АлАТ - $(1,64 \pm 0,21)$ ммоль/л-год, активність АсАТ - $(1,58 \pm 0,18)$ ммоль/л-год, індекс де Рітіса $-0,65 \pm 0,08$. Концентрація МСМ складала в середньому $(0,422 \pm 0,052)$ ум. од. У більшості хворих в першу добу після РЛ спостерігали високу активність продуктів перекисного окиснення ліпідів із підвищенням МДА до $(4,482 \pm 0,368)$ нмоль/мЛ та ДК до $(2,821 \pm 0,164)$ од. опт. щільн.

На 7-му добу після РЛ за шкалою Marshall J. C. MODS у 29 (80,6 \%) хворих становив 1-4 бали (прогнозована летальність 0-7 \%). Вміст лейкоцитів у периферичній крові становив в середньо- мy 7,5 \pm 0,81 x 109/л, рівень загального білірубіну в сироватці крові - $(17,1 \pm 1,9)$ мкмоль/л, активність АлАТ - $(0,83 \pm 0,06)$ ммоль/л-год, активність АсАТ - $(0,78 \pm 0,05)$ ммоль/л-год, індекс де Рітіса - $(0,95 \pm 0,13)$. Концентрація МСМ поверталася до норми і сягала $(0,298 \pm 0,027)$ ум. од. Середнє значення МДА становило $(3,62 \pm 0,24)$ нмоль/мЛ і ДК - $(1,41 \pm 0,09)$ од. опт. щільн., відповідно. У 7 (19,4 \%) з 36 хворих проводили повторні РЛ. У цих хворих MODS становив 9-12 балів (прогнозована летальність 50 \%). Померли 4 (11,1 \%) хворих від поліорганної недостатності.

У 44 (56 \%) хворих на розповсюджений ПП під час РЛ санацію черевної порожнини проводили розчином хлоргексидину. За шкалою Marshall J. C. в день РЛ 1-4 бали мали 9 хворих; 5-8 балів - 13 хворих; 9-12 балів - 22 хворих. Вміст лейкоцитів у периферичній крові в день РЛ у цих хворих становив в середньому 10,6 $\pm 1,1 \times 10 \%$ /л, piвень загального білірубіну в сироватці крові $(29,4 \pm 2,8)$ мкмоль/л, активність АлАТ - $(1,68 \pm$ $0,22)$ ммоль/л-год, активність АсАТ - $(1,62 \pm 0,21)$ ммоль/л-год, індекс де Рітіса - $(0,63 \pm 0,07)$. Концентрація МСМ складала в середньому $(0,428 \pm$ $0,048)$ ум. од., МДА - $(4,486 \pm 0,372)$ нмоль/мл та ДК - $(2,826 \pm 0,168)$ од. опт. щільн.

На 7-му добу після РЛ MODS тільки у 17 (38,6 \%) хворих становив 1-4 бали. Вміст лейкоцитів у периферичній крові складав в середньому 8,9 $\pm 0,86$ х 10\%/л, рівень загального білірубіну в сироватці крові - $(19,8 \pm 2,1)$ мкмоль/л, активність АлАТ - $(1,74 \pm 1,14)$ ммоль/л-год, активність АсАТ - $(1,82 \pm 1,16)$ ммоль/л-год, індекс де Рітіса $1,12 \pm 1,14$. Концентрація МСМ становила $(0,298 \pm$ $0,022)$ ум. од., МДА - $(3,79 \pm 0,26)$ нмоль/мл, ДК $(1,68 \pm 0,11)$ од. опт. щільн.

Повторні РЛ виконані у 27 (61,4 \%) із 44 хворих, з них по дві РЛ мали 19 (59,1 \%), по три РЛ 8 (40,9 \%). Причинами повторних РЛ у 5 (18,5 \%) хворих була недостатність швів міжкишкових анастомозів, у 14 (51,9 \%) - гостра стресова виразка шлунка, тонкої/товстої кишки, у 8 (29,6 \%) неефективне дренування міжпетлевих гнійників. MODS у цих хворих становив 9-12 балів (прогнозована летальність 50 \%). Помер 21 (47,7 \%) із 44 хворих внаслідок поліорганної недостатності.

Стартова антибактеріальна терапія була емпіричною, мала деескалаційний характер і передбачала комбінацію цефалоспоринів III-IV покоління (цефоперазон, цефепім) з антианаеробними препаратами (метрогіл, орнігіл). Після отримання результатів бактеріального дослідження та визначення чутливості мікрофлори до антибіоти- 
ків змінювали і антибактеріальні препарати. У 37 (46,3 \%) хворих із тяжким сепсисом із першого дня після РЛ застосували карбапенеми, зокрема, меронем (меропенем, ронем) у дозі 1,0 г внутрішньовенно 3 рази на добу. Для профілактики грибкової патологічної колонізації і суперінфекції призначали протигрибкові препарати - дифлюкан (флуконазол) в добовій дозі 50-100 мг.

При бактеріологічному дослідженні гною з черевної порожнини та порожнини абсцесів E. coli у концентрації 5 х $10^{6}$ мікробних тіл в 1 см$^{3}$ висіяли у 18 (22,5 \%) хворих, Pr. mirabilis у концентрації 5 х $10^{6}$ мікробних тіл в 1 см $^{3}$ - у 15 (18,8 \%) хворих, St. aureus у концентрації 5 х $10^{6}$ мікробних тіл в $1 \mathrm{~cm}^{3}$ - y 11 (13,8 \%) хворих, Ps. aeruginoza у концентрації 5 х 106 мікробних тіл в 1 см $^{3}-$ у 12 (15\%) хворих. Різноманітні комбінації цих збудників було встановлено - у 24 (30 \%) хворих. При бактеріологічному дослідженні крові і сечі результати були позитивними тільки у 19 (23,8 \%) хворих, у решти хворих росту мікроорганізмів не було незважаючи на неодноразовий посів.

Для екстракорпоральної детоксикації інтермітуючу вено-венозну гемодіафільтрацію, обмінний плазмаферез застосували у 31 (38,8 \%) із 80 хворих. Застосування цих методів сприяло зниженню рівня ендогенної інтоксикації, що сприяло полегшенню проявів мультиорганної дисфункції, а саме усуненню септичної енцефалопатії, покращенню оксигенації та вентиляції на фоні регресу гострого респіраторного дистрес-синдрому, відновленню функції нирок після первинного гострого їх пошкодження, корекції водно-електролітного дисбалансу та кислотно-лужної рівноваги, покращенню показників системної геодина-

\section{СПИСОК ЛІТЕРАТУРИ}

1. Бондарев Р. В. Сравнительные результаты лечения больных острым разлитым перитонитом при использовании методов хирургической детоксикации / Р. В. Бондарев, В. И. Бондарев // Український журнал хірургії. - № 2. - 2008. - С. 73-77. 2. Воронков Д. Є. Санація черевної порожнини в лікуванні розповсюдженого гнійного перитоніту / Д. Є. Воронов, О. В. Костирной, П. В. Поленок // Шпитальна хірургія. 2012. - № 4. - С. 114-116.

3. Гончар М. Г. Сучасні методи лікування термінальної фази загального перитоніту / М. Г. Гончар, Я. М. Кучірка // Український журнал хірургії. - 2011. - № 6 (15). - С. 90-92.

4. Жебровский В. В. Осложнения в хирургии живота: Руководство для врачей / [В. В. Жебровский, А. Д. Тимошин, С. В. Готье и др.]. - М. : ООО “Медицинское информационное агентство”, 2006. - 448 с.

5. Повторные операции при внутрибрюшных послеоперационных осложнениях / И. А. Криворучко, В. В. Бойко, міки. Така терапія також сприяла відновленню ефективної перистальтики кишечника.

Висновок. Таким чином, серед 80 хворих, яким виконали РЛ, за шкалою Marshall J.C., 9-12 балів встановлено у 34 (42,5 \%). Одна РЛ проведена у 46 (57,5 \%) хворих. По дві РЛ виконано у 26 (32,5 \%), по три РЛ - у 8 (10 \%) хворих. Виникнення потреби у проведенні повторних РЛ у 34 (42,5 \%) супроводжувалося значним зростанням рівня летальності. Так, після першої РЛ померли 7 (15,2 \%) із 46 хворих, після другої РЛ - 12 (63,2 \%) із 19, після третьої РЛ 6 (75 \%) із 8 хворих. Для діагностики абдомінального сепсису слід визначати рівень молекул середньої маси, продуктів перекисного окиснення ліпідів - малонового діальдегіду та дієнових кон'югат.

Застосування прецизійної техніки, лаважу черевної порожнини розчинами антисептиків (812 л) до чистих промивних вод, інтраабдомінальне застосування “Екстранілу”, назоінтестинальної інтубації тонкої кишки, поряд з іншими методами лікування, сприяли більш швидкій ліквідації ознак абдомінального сепсису, зниженню числа повторних РЛ, зменшенню післяопераційної летальності з 47,7 до 11,1 \%.

Перспективи подальших досліджень. Враховуючи високу летальність, у хворих на післяопераційний перитоніт, ускладнений абдомінальним сепсисом, необхідно проводити подальший пошук оптимальних методів хірургічного лікування цієї категорії хворих із пріоритетним застосуванням міні-інвазивних технологій, ціленаправленої антибіотикотерапії та екстракорпоральних методів детоксикації.

Ю. В. Иванова, Н. В. Красносельский // Клінічна хірургія. № 11-12. - 2008. - С. 50-51.

6. Попадюк О. Я. Застосування біодеградуючих полімерних матеріалів у абдомінальній хірургії / О. Я. Попадюк // Клінічна хірургія. - № 11.2 (908). - 2017. - С. 89.

7. Савельев В. С. Перитонит: Практическое руководство / В. С. Савельев, Б. Р. Гельфанд, М. И. Филимонов. - М. : Литтерра, 2006. - 208 с.

8. Шапринський В. О. Застосування програмованої релапаротомії в лікуванні післяопераційного перитоніту / В. О. Шапринський // Клінічна хірургія. - 1997. - № 3-4. - С. 74-76.

9. Dhainaut J. F. Protein C/activatedprotein C pathway: overview of clinical trial results insevere sepsis / J. F. Dhainaut, S. B. Yan, Y. E. Cleassens //Crit. Care Med. - 2004. - Vol. 32. - P. 194-201. 10. Foitzik T. Persistent multiple organ microcirculatory disorders in severe sepsis. Experimental findings and clinical implications / T. Foitzik, B. Hotz // Dig. Dis. Sci. - 2002. - Vol. 47. - P. 130-138 


\section{З ДОСВІДУ РОБОТИ}

\section{REFERENCES}

1. Bondarev, R.V. \& Bondarev, V.I. (2008). Sravnitelnye rezultaty lecheniya bolnykh ostrym razlitim peritonitom pri ispolsovanii metodov khirurgicheskoy detoksikatsii [Comparative results of treatment of patients with acute diffuse peritonitis using surgical detoxification methods]. Ukrainskyi zhurnal khirurhii - Ukrainian Journal of Surgery, 2, 73-77 [in Ukrainian].

2. Voronov, D.Ye., Kostyrnoi, O.V. \& Polenok, P.V. (2012). Sanatsiia cherevnoi porozhnyny v likuvanni rozpovsiudzhenoho hniinoho perytonitu [Rehabilitation of the abdominal cavity in the treatment of diffuse purulent peritonitis]. Shpytalna khirurhiia Hospital Surgery, 4, 114-116 [in Ukrainian].

3. Honchar, M.H. \& Kuchirka, Ya.M. (2011). Suchasni metody likuvannia terminalnoi fazy zahalnoho perytonitu [Modern methods of treatment of the terminal phase of general peritonitis]. Ukrainskyi zhurnal khirurhii - Ukrainian Journal of Surgery, 6 (15), 90-92 [in Ukrainian].

4. Zhebrovskyy, V.V., Timoshin, A.D. \& Gotye S.V. (2006). Oslozhneniya $v$ khirurgii zhivota: Rukovodstvo dlya vrachey [Complications in abdominal surgery: Manual for Doctors]. Moscow: OOO "Meditsinskoye informatsionnoe agenstvo" [in Russian].

5. Kryvoruchko, I.A., Boyko, V.V., Ivanova, Yu.V. \& Krasnoselskiy, N.V. et al. (2008). Povtornye operatsii pri vnutribryu- shnykh posleoperatsionnykh oslozhneniyakh [Repeated operations with intra-abdominal postoperative complications]. Klinichna Khirurhiia - Clinical Surgery, 11-12, 50-51 [in Ukrainian]. 6. Popadiuk, O.Ya. (2017). Zastosuvannia biodehraduiuchykh polimernykh materialiv u abdominalnii khirurhii [Application of biodegradable polymeric materials in abdominal surgery]. Klinichna Khirurhiia - Clinical Surgery, 11.2 (908), 89 [in Ukrainian].

7. Savelyev V.S., Gelfand, B.R. \& Philimonov, M.I. (2006). Peritonit: Prakticheskoye rukovodstvo [Peritonitis: Practical Guide]. Moskow: Literra [in Russian].

8. Shaprynskyi V.O. (1997). Zastosuvannia prohramovanoi relaparotomii $\mathrm{v}$ likuvanni -pisliaoperatsiinoho perytonitu [Application of programmable relaparotomy in the treatment of postoperative peritonitis]. Klinichna Khirurhiia - Clinical Surgery, 3-4, 74-76 [in Ukrainian].

9. Dhainaut, J.F., Yan, S.B., \& Cleassens, Y.E. (2004). Protein C/ activatedprotein $\mathrm{C}$ pathway: overview of clinical trial results in severe sepsis. Crit. Care Med., 32, 194-201.

10. Foitzik, T., \& Hotz, B. (2002). Persistent multiple organ microcirculatory disorders in severe sepsis. Experimental findings and clinical implications. Dig. Dis. Sci., 47, 130-138.

Отримано 26.01.2018

\section{M. SHEVCHUK, M. M. DRONYAK, O. YA. POPADYUK, M. B. FEDORKIV, V. M. DRONYAK}

Ivano-Frankivsk National Medical University

\section{RESULTS OF SURGICAL TREATMENT OF PATIENTS WITH POSTOPERATIVE PERITONITIS}

The aim of the study. To improve the results of surgical treatment of patients with postoperative peritonitis complicated by abdominal sepsis, by improving timely diagnosis and implementation of optimal surgical tactics.

Materials and Methods. In 2010-2017, intraperitoneal complications were diagnosed in 209 (2.4 \%) among 8762 patients operated after acute and chronic diseases of the abdominal cavity.

Results and Discussion. Abscesses of the abdominal cavity take place in 142 (67.9 \%) cases, generalized peritonitis - 67 (42.1 \%) patients. Mini invasive techniques (laparoscopic sanation of abscesses in the abdominal cavity with drainage of abscesses by styletcatheter under ultrasound guidance) were effective in 129 (61.7 \%) cases. Relaparotomy (RL) was performed in 80 (38.3 \%) cases. Among them: in patients with generalized postoperative peritonitis in 61 (91\%) among 67 patients, with localized postoperative peritonitis - in 19 (13.4\%) of 142 patients. The first manifestations of intraabdominal complications after postoperative peritonitis were: the acute respiratory failure - in 95 (45.5\%) cases, cardiovascular failure - in 68 (32.5\%) cases, liver and renal dysfunction - in 46 (22\%) cases in the absence of clear local signs of the disease. 34 (42.5\%) out of 80 patients, who underwent the relaparotomy had 9-12 points of the Marshall score. One relaparotomy was performed in 46 (57.5 \%) cases. Two relaparotomies were performed in 26 (32.5 \%) cases, three relaparotomies - in 8 (10 \%) cases. The need to repeat relaparotomy in 34 (42.5 \%) cases was accompanied by a significant increase of mortality. So, after the first relaparotomy, 7 (15.2\%) out of 46 patients died, after the second relaparotomy - 12 (63.2 \%) out of 19, after the third relaparotomy 6 (75\%). The use of precision technology, lavages of the abdominal cavity with solutions of antiseptics (8-12 liters) untill clean waters, intraabdominal applications of "Extranil", nasointetestinal intubation of the small intestine with other methods of treatment, helped to accelerate the elimination of signs of abdominal sepsis, decrease in the number of repeated relaparotomy, decrease postoperative lethality from 47.7 to $11.1 \%$.

Key words: postoperative peritonitis; relaparotomy; abdominal sepsis. 
И. М. ШЕВЧУК, Н. Н. ДРОНЯК, О. Я. ПОПАДЮК, М. Б. ФЕДОРКИВ, В. Н. ДРОНЯК

Ивано-Франковский национальный медицинский университет

\section{РЕЗУЛЬТАТЫ ХИРУРГИЧЕСКОГО ЛЕЧЕНИЯ БОЛЬНЫХ ПОС.ЛЕОПЕРАЦИОННЫМ ПЕРИТОНИТОМ}

Цель работы: улучшить результаты хирургического лечения больных послеоперационным перитонитом, осложненным абдоминальным сепсисом, путем улучшения своевременной диагностики и внедрения оптимальной хирургической тактики. Материалы и методы. По 2010-2017 гг. внутрибрюшинные осложнения диагностированы у 209 (2,4 \%) из 8762 больных, перенесших операцию на острые и хронические заболевания органов брюшной полости.

Результаты исследований и их обсуждение. Абсцессы брюшной полости виявлены у 142 больных (67,9 \%), распространенный перитонит - у 67 (42,1 \%) больных. Мини-инвазивные технологии (лапароскопические вмешательства, дренирование гнойника под контролем УЗИ) были эффективными в 129 (61,7 \%) больных. Релапаротомию (РЛ) выполнили в 80 (38,3 \%) больных, из них при распространенном перитоните - в 61 (91 \%) из 67 больных, при абсцессах брюшной полости - у 19 (13,4 \%) из 142 больных. Первые проявления интраабдоминальных осложнений носили характер острой дыхательной недостаточности - в 95 (45,5 \%), сердечно-сосудистой недостаточности - в 68 (32,5 \%), печеночно-почечной дисфункции - у 46 (22 \%) больных при отсутствии четких местных признаков заболевания. Среди 80 больных, которым выполнили РЛ, по шкале Мarshall J.С., 9-12 баллов установлено у 34 (42,5 \%). Одна РЛ проведена в 46 (57,5 \%) больных. По две РЛ выполнено у 26 (32,5 \%), по три РЛ - у 8 (10 \%) больных. Возникновение потребности в проведении повторных РЛ у 34 (42,5 \%) сопровождалось значительным ростом уровня летальности. Так, после первой РЛ умерли 7 (15,2 \%) из 46 больных, после второй РЛ - 12 (63,2 \%) из 19, после третьей РЛ 6 (75 \%) из 8 больных. Применение прецизионной техники, лаважа брюшной полости растворами антисептиков (8-12 л) до чистых промывных вод, интраабдоминальные применения “Екстранила”, назоинтестинальной интубации тонкой кишки, наряду с другими методами лечения, способствовали более быстрой ликвидации признаков абдоминального сепсиса, снижению числа повторных РЛ, уменьшению послеоперационной летальности с 47,7 до 11,1%.

Ключевые слова: послеоперационный перитонит; релапаротомия; абдоминальный сепсис. 